\title{
The Influence of Oil Raw Materials on The Quality of Finished Soap Products in The Laboratory Division at PT. Solar Wings Corps.
}

\author{
Rachmad Hidayat ${ }^{1}$, Hidayat $^{2}$, Rifky Maulana Yusron ${ }^{3}$, Wasiur ${ }^{2}$, and Moh. Jufriyanto ${ }^{2}$ \\ ${ }^{1}$ Department of Industrial Engineering, University of Trunojoyo Madura, Bangkalan 69162, Indonesia \\ ${ }^{2}$ Department of Industrial Engineering, University of Muhammadiyah Gresik, Bangkalan 61121, Indonesia \\ ${ }^{3}$ Department of Mechanical Engineering, University of Trunojoyo Madura, Bangkalan 69162, Indonesia
}

\begin{abstract}
The business actors are required to generate the maximum profit possible, thus demanding workers to work productively. This cannot be denied because workers are the most essential element in running the company's wheels. PT Wings Surya is a manufacturing company that produce soap. this research activity focuses on how to check soap products using the AOCS Method, in which the AOCS (The American Oil Chemists' Society) method is a method applied to measure and analyze levels in oil so that it is known whether these levels already meet the standards to be processed into a quality product. The quality of the finished soap product can be determined and anticipated by looking at the quality of the Iodide Value, Peroxide Value, and Saponification Value of the raw oil used for the soap product. The finished product of soap at PT. Wings Surya in November based on the quality of the raw material used, it will produce a finished product of soap with good quality but not with the rancid smell caused by the raw material of the oil it self.
\end{abstract}

Keywords: AOCS Method, Oil Raw Material, Soap Product, Iodide Value

\section{Introduction}

In industry, business actors are required to generate the maximum profit possible, thus demanding workers to work productively [1][2]. This cannot be denied because workers are the most essential element in running the company's wheels [3]. Both field and non-field workers. Workers are required to produce as many good quality products as possible in a short period of time [4][5]. This causes problems in quality, especially in outspec products that often occur in production results so that there is a decrease in quality where the products produced do not meet the quality standards that have been determined and with the emergence of these events can affect the quality of the product so it must be rejected [6][7][8].

The product is a set of attributes, both tangible and intangible, including color, price, the good name of the factory, the good name of the store that sells (retailer), and factory services and retailer services, which are accepted by buyers to satisfy their desires [10][11].

Soap is a skin cleansing preparation made from the saponification or neutralization process of fats, oils, waxes, rosin or acids with organic or inorganic bases without causing irritation to the skin [12][13]. Quality is a direct description of a product such as performance, reliability, ease of use, aesthetics and so on[14]. In definition strategically, quality is everything that is able to meet the desires or needs of customers Oils and fats are one of the groups belonging to the lipid group, which are organic compounds that occur in nature and are insoluble in water, but soluble in non-polar organic solvents, for example diethyl ether, chloroform, and other hydrocarbons. Oils and fats can be dissolved in the solvents mentioned above because oils and fats have the same polarity as the solvent [15][16].

AOCS (The American Oil Chemists' Society) is an international professional organization based in Urbana, Illinos USA dedicated to providing a support network for those involved with science and technology relating to fats, oils, surfactants and other related ingredients [17] [18].

AOCS' mission is to provide a high standard of quality among those with a professional interest in the science and technology of fats, oils, surfactants and other related materials and to help professionals maintain an edge in their industry [19][20].

The official methods and recommended practices of the AOCS are widely used in hundreds of laboratories on six continents. The method deals with fats, oils and lipids which are important for processing and trading [21][22].

\footnotetext{
*Corresponding author : hidayat@umg.ac.id
} 
Before the arrival of the oil, the oil must be checked and analyzed for levels, the products that have been analyzed and the results meet the specified standards will be sent to the warehouse which will then be received and stored to wait for use by the stockes section [23]. And if the results do not meet the standard, the product will be rejected, and this will increase the company's expenses for return costs [24][25]. Improper storage conditions in the presence of excessive temperatures in raw materials can be one of the factors causing damage to products that will be used as raw materials for making oil[26][27]. The research is held on PT Wings Surya Company which produce the soap.

The following is the Outspec data from the analysis of raw materials for oil taken from August 2020 to October 2020. The data is the average analysis result within a month.

Table 1. Oil Outspec Data (August 2020-October 2020)

\begin{tabular}{|c|c|c|c|}
\hline Period & Oil Types & Parameter & Average \\
\hline \multirow{3}{*}{ August } & Stearine & $\begin{array}{l}\text { Perokside } \\
\text { Value }\end{array}$ & 0.288 \\
\hline & $\begin{array}{l}\text { Refined } \\
\text { Bleached } \\
\text { Deodorized } \\
\text { Palm Oil } \\
\text { (RBDPO) }\end{array}$ & $\begin{array}{l}\text { Perokside } \\
\text { Value }\end{array}$ & 0.262 \\
\hline & $\begin{array}{l}\text { Palm } \\
\text { Kernel Oil } \\
(\mathrm{PKO})\end{array}$ & $\begin{array}{l}\text { Perokside } \\
\text { Value }\end{array}$ & 0.189 \\
\hline \multirow{3}{*}{ September } & Stearine & $\begin{array}{l}\text { Perokside } \\
\text { Value }\end{array}$ & 0.455 \\
\hline & $\begin{array}{l}\text { Refined } \\
\text { Bleached } \\
\text { Deodorized } \\
\text { Palm Oil } \\
\text { (RBDPO) }\end{array}$ & $\begin{array}{l}\text { Perokside } \\
\text { Value }\end{array}$ & 0.302 \\
\hline & $\begin{array}{l}\text { Palm } \\
\text { Kernel Oil } \\
(\mathrm{PKO})\end{array}$ & $\begin{array}{l}\text { Perokside } \\
\text { Value }\end{array}$ & 0.206 \\
\hline \multirow{3}{*}{ October } & Stearine & $\begin{array}{l}\text { Perokside } \\
\text { Value }\end{array}$ & 0.339 \\
\hline & $\begin{array}{l}\text { Refined } \\
\text { Bleached } \\
\text { Deodorized } \\
\text { Palm Oil } \\
\text { (RBDPO) }\end{array}$ & $\begin{array}{l}\text { Perokside } \\
\text { Value }\end{array}$ & 0.298 \\
\hline & $\begin{array}{l}\text { Palm } \\
\text { Kernel Oil } \\
(\mathrm{PKO})\end{array}$ & $\begin{array}{l}\text { Perokside } \\
\text { Value }\end{array}$ & 0.208 \\
\hline
\end{tabular}

Table 1 is a table that contains Outspec data carried by several types of oil from August 2020 to October 2020. The Outspec carried by several types of oil is the Outspec Peroxide Value, which can cause the oil to emit a rancid odor.

Based on the background that has been described, this research activity will focus on how to check soap products using the AOCS Method, in which the AOCS (The American Oil Chemists' Society) method is a method applied to measure and analyze levels in oil so that it is known whether these levels already meet the standards to be processed into a quality product

\section{Methods}

\subsection{Data Collection}

The collection of data that has been collected is the data obtained in research conducted by direct observation at PT. Wings Surya during November 2020.

\subsection{Standard Data for Oil Raw Materials}

In the process of analyzing raw materials for oil, there is a reference standard for oil content used by PT. Wings Surya to produce good quality products. The following is the standard data for oil raw materials:

\subsubsection{Stearine Oil}

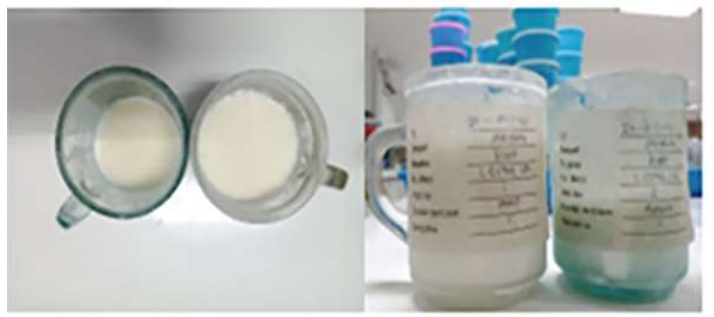

(a)

(b)

Fig. 1 Stearine oil standard

(a) left: stearine oil with a high peroxide value, right: stearine oil with a standard peroxide value. (b) sample description on stearine oil

\subsubsection{Refined Bleached Deodorized Palm Oil $(R B D P O)$}

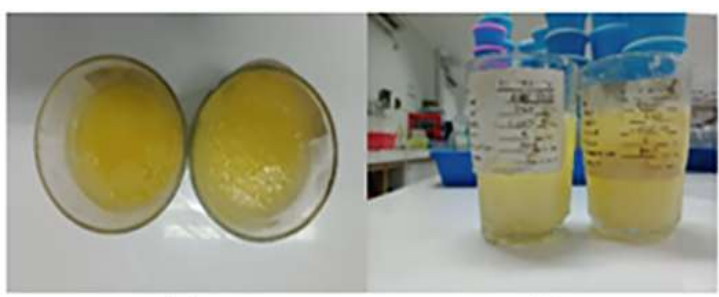

(a)

(b)

Fig. 2 Standard for Refined Bleached Deodorized Palm Oil (RBDPO)

(a) left: RBDPO oil with a high peroxide value, right: RBDPO oil with a standard peroxide value. (b) sample description on RBDPO oil 


\subsubsection{Palm Kernel Oil (PKO)}

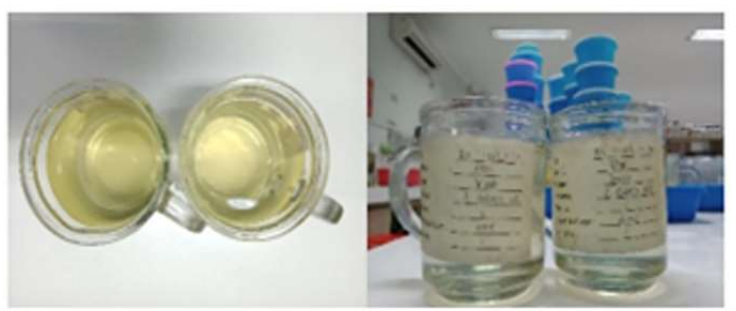

(a)

(b)

Fig. 3 Palm Kernel Oil (PKO) oil standard

(a) left: PKO oil with high peroxide value, right: PKO oil with standard peroxide value. (b) sample description on PKO oil

Parameter of each oil type and standards shown on table 2.

Table 2. Standard oil raw materials

\begin{tabular}{|c|c|c|}
\hline Oil types & Parameters & Standard \\
\hline \multirow{3}{*}{ Stearine } & Iodide Value $\left(\mathrm{Cgl}_{2} / \mathrm{gr}\right)$ & $34-37$ \\
\hline & $\begin{array}{l}\text { Perokside } \\
\left(\mathrm{mgO}_{2} / \mathrm{gr}\right)\end{array}$ & 2 \\
\hline & $\begin{array}{l}\text { Saponification } \\
(\mathrm{mgKOH} / \mathrm{gr})\end{array}$ & $195-205$ \\
\hline \multirow{3}{*}{$\begin{array}{l}\text { Refined } \\
\text { Bleached } \\
\text { Deodorized } \\
\text { Palm Oil } \\
\text { (RBDPO) }\end{array}$} & Iodide Value $\left(\mathrm{Cgl}_{2} / \mathrm{gr}\right)$ & $51.5-53$ \\
\hline & $\begin{array}{l}\text { Perokside } \\
\left(\mathrm{mgO}_{2} / \mathrm{gr}\right)\end{array}$ & 2 \\
\hline & $\begin{array}{l}\text { Saponification } \\
(\mathrm{mgKOH} / \mathrm{gr})\end{array}$ & $195-205$ \\
\hline \multirow{3}{*}{$\begin{array}{l}\text { Palm } \\
\text { Kernel Oil } \\
(P K O)\end{array}$} & Iodide Value $\left(\mathrm{Cgl}_{2} / \mathrm{gr}\right)$ & $17-20$ \\
\hline & $\begin{array}{l}\text { Perokside } \\
\left(\mathrm{mgO}_{2} / \mathrm{gr}\right)\end{array}$ & 1 \\
\hline & $\begin{array}{l}\text { Saponification Value } \\
(\mathrm{mgKOH} / \mathrm{gr})\end{array}$ & $245-255$ \\
\hline
\end{tabular}

\section{Results and Discussions}

Identifying Sources and Root Causes of Soap Quality Problems Due to Raw Materials. The sources and root causes of problems in soap quality are determined based on the results of the analysis of raw oil materials for each parameter. The method used to identify the root of this problem is to observe and interview directly to the Sub Selection Head Laboratory of PT. Wings Surya, Mrs. Titik Marliyah who already has sufficient work experience (18 years) who has the ability to identify the sources and root causes of problems in soap quality due to raw materials shown on table 3 .
Table 3. Root Causes of Soap Quality Problems Due to

\begin{tabular}{|c|c|}
\hline \multicolumn{2}{|c|}{ Raw Materials } \\
\hline Causes & Quality problem of Soap \\
\hline \multirow{2}{*}{ Iodide Value } & $\begin{array}{l}\text { Too high causes the soap to not } \\
\text { freeze (harden) }\end{array}$ \\
\hline & $\begin{array}{l}\text { Too low causes the soap to be } \\
\text { too hard }\end{array}$ \\
\hline \multirow[b]{2}{*}{ Perokside Value } & $\begin{array}{l}\text { Too high causes a rancid } \\
\text { smell to the oil }\end{array}$ \\
\hline & $\begin{array}{l}\text { Too high causes a rancid } \\
\text { odor in the finished product } \\
\text { of soap }\end{array}$ \\
\hline $\begin{array}{l}\text { Saponification } \\
\text { Value }\end{array}$ & $\begin{array}{l}\text { Too high, the more reactions } \\
\text { needed, so more base is } \\
\text { needed }\end{array}$ \\
\hline
\end{tabular}

\subsection{Data Processing}

In the first data processing stage, an analysis is carried out on each type of oil raw material with the level parameters that have been determined by PT. Solar Wings. From the results of the analysis carried out, it can be seen the results of the content of the raw material of oil so that it can be determined that the oil can be used as raw material for products with good quality. Those who determine the use of the oil as raw material for the production are Mrs. Oei Meliana Wibisono as the Department Head and Mrs. Titik Marliyah as the Sub Selection Head of the company's laboratory who already has sufficient work experience (18 years) and has the ability to assess the quality of a product.

\subsection{Analysis of Oil Raw Materials}

Analysis of oil raw materials is carried out by laboratory analysts every time there is an arrival of oil to be used as raw material for soap products. The analysis includes: Analysis of Iodide Value, Peroxide Value, and Saponification Value.

In the analysis process, there were ups and downs in the results of the oil analysis that occurred in the November 2020 period. The following are the results of the oil analysis during the November 2020 period.

Out Specs Less

Out Specs More 
Table 4. Analysis Results During November 2020 at PT. Solar Wings.

\begin{tabular}{|c|c|c|c|c|c|c|c|c|c|}
\hline \multirow{3}{*}{$\begin{array}{l}\text { Analysis } \\
\text { Date }\end{array}$} & \multicolumn{9}{|l|}{ Results } \\
\hline & \multicolumn{3}{|c|}{ Stearine } & \multicolumn{3}{|c|}{ RBDPO } & \multicolumn{3}{|l|}{ РКО } \\
\hline & IV & PV & SV & IV & PV & SV & IV & PV & SV \\
\hline \multicolumn{10}{|l|}{$11 / 01 / 2020$} \\
\hline \multirow{2}{*}{$11 / 02 / 2020$} & \multirow{2}{*}{33.349} & 0.683 & \multirow{2}{*}{200.59} & \multirow{2}{*}{51.606} & 0.361 & \multirow{2}{*}{199.21} & 17.612 & 0.201 & 245.89 \\
\hline & & 0.522 & & & 0.261 & & & & \\
\hline \multirow{2}{*}{$11 / 03 / 2020$} & \multirow{2}{*}{34.048} & 0.362 & \multirow{2}{*}{200.4} & \multirow{2}{*}{51.757} & 0.281 & \multirow{2}{*}{198.99} & 17.473 & 0.201 & 245.03 \\
\hline & & 0.402 & & & 0.281 & & & & \\
\hline \multirow{4}{*}{$11 / 04 / 2020$} & \multirow{4}{*}{34.621} & 0.281 & \multirow{4}{*}{199.46} & \multirow{2}{*}{51.623} & 0.241 & \multirow{2}{*}{198.23} & & & \\
\hline & & 0.281 & & & 0.241 & & & & \\
\hline & & 0.321 & & & & & & & \\
\hline & & 0.241 & & & & & & & \\
\hline \multirow{4}{*}{$11 / 05 / 2020$} & \multirow{4}{*}{34.197} & 0.281 & \multirow{4}{*}{198.68} & 51515 & 0.241 & 10702 & & & \\
\hline & & 0.281 & & ה10 & 0.281 & 191.00 & & & \\
\hline & & 0.281 & & & & & & & \\
\hline & & 0.241 & & & & & & & \\
\hline $11,06 / 2020$ & 24100 & 0.361 & $100-51$ & 51742 & 0.241 & 10072 & & & \\
\hline $11 / 2012020$ & 34.100 & 0.402 & (19. & $21.1+2$ & 0.241 & 170.12 & & & \\
\hline $11 / 07 / 2020$ & & & & & & & & & \\
\hline $11 / 08 / 2020$ & & & & & & & & & \\
\hline & & 0.241 & & 52.764 & 0.241 & 200.66 & & 0.241 & \\
\hline $11 / 09 / 2020$ & 34.455 & 0.260 & 202.94 & & & & 17.211 & 0.241 & 245.26 \\
\hline & & 0.241 & & & & & & 0.220 & \\
\hline & & 0.281 & & 52564 & 0.321 & 10072 & 17716 & 0.241 & 24600 \\
\hline & & 0.402 & & 52.504 & 0.320 & 198.13 & $1 / .110$ & 0.241 & 240.08 \\
\hline $11 / 1082020$ & 34.314 & 0.402 & 201.00 & & & & & & \\
\hline & & 0.281 & & & & & & & \\
\hline & & 0.281 & & 52.300 & 0.361 & 199.32 & 17476 & 0.241 & 24767 \\
\hline 11/11/200 & 24101 & 0.261 & 50155 & & & & & 0.241 & 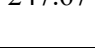 \\
\hline 117112020 & 样 & 0.261 & 201.03 & & & & & & \\
\hline & & 0.321 & & & & & & & \\
\hline & & 0.362 & & 51.869 & 0.281 & 197.22 & 18012 & 0.241 & 21561 \\
\hline & & 0.281 & & & & & 10.012 & 0.281 & 245.01 \\
\hline 111 1 2 - & ערוע & 0.281 & ד.0 & & & & & & \\
\hline & & 0.241 & & & & & & & \\
\hline & & 0.281 & & 52.596 & 0.361 & 198.21 & 17.411 & 0.241 & 245.13 \\
\hline & & 0.442 & & & & & & & \\
\hline & & 0.442 & & & & & & & \\
\hline $11 / 10 / 20$ & 34.250 & 0.321 & 199.00 & & & & & & \\
\hline & & 0.361 & & & & & & & \\
\hline & & 0.361 & & & & & & & \\
\hline
\end{tabular}




\begin{tabular}{|c|c|c|c|c|c|c|c|c|c|}
\hline & & 0.361 & & & & & & & \\
\hline \multicolumn{10}{|c|}{$11 / 14-15 / 20$} \\
\hline \multirow{5}{*}{$11 / 16 / 20$} & 34.077 & 0.322 & 201.42 & \multirow{5}{*}{52.192} & 0.281 & \multirow{5}{*}{197.45} & & & \\
\hline & & & & & 0.321 & & & & \\
\hline & & & & & 0.321 & & & & \\
\hline & & & & & 0.402 & & & & \\
\hline & & & & & 0.281 & & & & \\
\hline \multirow{5}{*}{$11 / 17 / 20$} & & 0.481 & \multirow{3}{*}{200.60} & & 0.281 & \multirow{5}{*}{198.07} & & & \\
\hline & 34.053 & 0.480 & & & 0.281 & & & & \\
\hline & & 0.422 & & 52.530 & 0.321 & & & & \\
\hline & & & & & 0.201 & & & & \\
\hline & & & & & 0.281 & & & & \\
\hline \multirow{6}{*}{$11 / 18 / 20$} & & 0.321 & \multirow{4}{*}{201.82} & \multirow{6}{*}{52.250} & 0.281 & \multirow{6}{*}{199.04} & & & \\
\hline & & 0.301 & & & 0.241 & & & & \\
\hline & 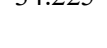 & 0.301 & & & 0.364 & & & & \\
\hline & & 0.341 & & & 0.220 & & & & \\
\hline & & & & & 0.241 & & & & \\
\hline & & & & & 0.281 & & & & \\
\hline \multirow{2}{*}{$11 / 19 / 20$} & \multirow{2}{*}{34.414} & 0.301 & \multirow{2}{*}{201.82} & 51.774 & 0.241 & 200.11 & & & \\
\hline & & 0.281 & & & & & & & \\
\hline \multirow{3}{*}{$11 / 20 / 20$} & \multirow{3}{*}{34.035} & 0.238 & \multirow{3}{*}{201.66} & \multirow{3}{*}{52.658} & 0.241 & \multirow{3}{*}{199.48} & \multirow{2}{*}{17.282} & 0.199 & \multirow{2}{*}{245.90} \\
\hline & & 0.281 & & & 0.241 & & & 0.199 & \\
\hline & & 0.241 & & & 0.241 & & & & \\
\hline \multirow{2}{*}{$11 / 21 / 20$} & \multirow{2}{*}{34.465} & 0.301 & 20204 & & & & & & \\
\hline & & 0.238 & 202.94 & & & & & & \\
\hline $11 / 22 / 20$ & & & & & & & & & \\
\hline $11 / 2200$ & & & & 52006 & 0.341 & 20020 & 17006 & 0.241 & 21725 \\
\hline 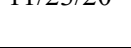 & & & & 52.700 & 0.238 & 200.02 & & 0.201 & 291.00 \\
\hline & & 0.281 & & & & & & 0.221 & \\
\hline & 34.134 & 0.238 & 201.90 & & & & & 0.201 & \\
\hline $11124 / 20$ & & & & & & & 11.070 & 0.221 & $240.0 \mathrm{~J}$ \\
\hline & & & & & & & & 0.198 & \\
\hline $11 / 25 / 20$ & 34.592 & 0.238 & 199.85 & & & & 17.344 & 0.199 & 245.98 \\
\hline & & 0.238 & & & & & & & \\
\hline $11 / 26 / 20$ & 34.567 & 0.238 & 199.98 & & & & & & \\
\hline & & 0.238 & & & & & & & \\
\hline & & 0.596 & & & & & 17.616 & 0.238 & 245.48 \\
\hline $11 / 27 / 20$ & 34.874 & 0.437 & 200.99 & & & & & & \\
\hline & & 0.476 & & & & & & & \\
\hline $11 / 28-29 / 2$ & & & & & & & & & \\
\hline & & & & & & & & 0.241 & \\
\hline 11730120 & & & & & & & 11.08 & 0.201 & (2ד. \\
\hline Average & 34.300 & 0.329 & 200.89 & 52.170 & 0.282 & 198.80 & 17.590 & 0.225 & 242.53 \\
\hline
\end{tabular}




\section{Conclusions}

The conclusions that can be given in this study are as follows:

a. The quality of the finished soap product can be determined and anticipated by looking at the quality of the Iodide Value, Peroxide Value, and Saponification Value of the raw oil used for the soap product.

b. The finished product of soap at PT. Wings Surya in November based on the quality of the raw material used, it will produce a finished product of soap with good quality but not with the rancid smell caused by the raw material of the oil itself.

\section{References}

[1] V.N. Castelo-Branco, I. Santana, V.O. Di-Sarli, S.P. Freitas, A.G. Torres, Antioxidant capacity is a 364 surrogate measure of the quality and stability of vegetable oils, European Journal of Lipid Science and 365 Technology, 118 (2016) 224-235. 366

[2] E. Choe, D.B. Min, Mechanisms and Factors for Edible Oil Oxidation, Comprehensive Reviews in Food 367 Science and Food Safety, 5 (2006) 169-186. 368

[3] Y. Yang, Q. Li, X. Yu, X. Chen, Y. Wang, A novel method for determining peroxide value of edible oils 369 using electrical conductivity, Food Control, 39 (2014) 198-203. 370

[4] M. Wang, Z. Huyan, B. Jing, X. Mao, X. Yu, Analysis of Edible Oil Oxidation Based on Changes in the 371 Electrical Conductivity of the electronic nose and electronic 388 tongue, Food Chemistry, 101 (2007) 485-491. 389

[5] L. Xu, X. Yu, 1. Liu, R. Zhang, A novel method for qualitative analysis of edible oil oxidation using an 374 electronic nose, Food Chemistry, 202 (2016) 229-235. 375

[6] L. Xu, X. Yu, L. Liu, R. Zhang, A novel method for qualitative analysis of edible oil oxidation using an 376 electronic nose, Food Chemistry, 202 (2016) 229-235. 377

[7] J. Li, W. Cai, D. Sun, Y. Liu, A Quick Method for Determining Total Polar Compounds of Frying Oils 378 Using Electric Conductivity, Food Analytical Methods, 9 (2016) 1444-1450. 379

[8] M. Śliwińska, P. Wiśniewska, T. Dymerski, J. Namieśnik, W. Wardencki, Food Analysis Using Artificial 380 Senses, Journal of Agricultural and Food Chemistry, 62 (2014) 1423-1448. 381

[9] E.A. Baldwin, J. Bai, A. Plotto, S. Dea, Electronic noses and tongues: applications for the food and 382 pharmaceutical industries, Sensors (Basel), 11 (2011) 4744-4766. 383

[10] S. Mildner-Szkudlarz, H.H. Jeleń, R. ZawirskaWojtasiak, The use of electronic and human nose for 384 monitoring rapeseed oil autoxidation, European Journal of Lipid Science and Technology, 110

[11] M.S. Cosio, D. Ballabio, S. Benedetti, C. Gigliotti, Evaluation of different storage conditions of extra 387 virgin olive oils with an innovative recognition tool built by means of Extracted Aqueous (2008) 61-385 72. 386

[12] M.J. Lerma-García, E.F. Simó-Alfonso, A. Bendini, L. Cerretani, Metal oxide semiconductor sensors 390 for monitoring of oxidative status evolution and sensory analysis of virgin olive oils with different 391 phenolic content, Food Chemistry, 117 (2009) 608-614. 392

[13] Y. Yin, Y. Zhao, A feature selection strategy of E-nose data based on PCA coupled with Wilks $\Lambda$-393 statistic for discrimination of vinegar samples, Journal of Food Measurement and Characterization, 13394 (2019) 2406-2416. 39

[14] Official Methods and Recommended Practices of the AmericanOil Chemists' Society, 4th edn., edited by D. Firestone, Ameri-can Oil Chemists' Society, Champaign, 1997, Method Cd 8-53.

[15] Shantha, N.C., and E.A. Decker, Rapid, Sensitive, Iron-Based Spectrophotometric Methods for Determination of Peroxide Values of Food Lipids, J. AOAC Int. 77:421-424 (1994).

[16] Hara, S., and Y. Totani, A Highly Sensitive Method for the Micro-determination of Lipid Hydroperoxides by Potentiome- try, J. Am. Oil Chem. Soc. 65:1948-1950 (1988).

[17] Hamm, D.L., E.G. Hammond, V. Parvanah, and H.E. Snyder, The Determination of Peroxides by the Stamm Method, Ibid. 42:920-922 (1965).

[18] Dong, J., K. Ma, F.R. van de Voort, and A.A. Ismail, Stoichio-metric Determination of Hydroperoxides in Oils by Fourier Transform Near-Infrared Spectroscopy, J. AOAC Int. 80:345-352 (1997).

[19] Official Methods of Analysis of AOAC International, 16th edn.,AOAC International, Gaithersburg, 1997.

[20] SAS/STAT User's Guide, SAS Institute Inc. Cary, North Car-olina, 1990

[21] Mehlenbacher, V.C., The Analysis of Fats and Oils, Garrard Press, Champaign, (1960), pp. 219-227.

[22] Mair, R.D., and R.T. Hall, Determination of Organic Peroxides by Physical, Chemical and Colorimetric Methods, in Organic Peroxides, edited by D. Swern, Wiley Interscience, New York, (1971), pp. 535-636

[23] Abd Gani, S.S., Mokhtar, N.F., Zaidan, U.H., Borhan, F.P., Talha, K., Azahar, N.F., 2018. Optimization of Moisturizing Clay Soap Containing Pitaya (Hylocereus Polyrhizus) SeedExtract using D-Optimal Mixture 
Experimental Design. Journal of Advanced Research in Fluid Mechanics and Thermal Sciences, Vol 43(1), pp. 45-57

[24] Adamis, Z., Fodor, J., Williams, R.B., 2005. Environmental Health Criteria 231, Bentonite, Kaolin and Selected Clay Minerals. Available Onlinehttps://www.who.int/ipcs/publications/eh c/ehc_231.pdf, Accessed on May 22, (2020).

[25] Araseretnam, S., Venujah, K., 2019. Preparation of Soaps by using Different Oil and Analyze their Properties. Journal Natural Products Chemistry and Research, Volume 7(1), pp. 1-4

[26] Asad, Md.A., Shantanu, Kar., Ahmeduzzaman, M., Raquibul Hassan, M., 2013. Suitable of Bentonite Clay: An analytical Approach. International Journal of Earth Science, Vol 2 (3), pp. 88-95

[27] Awang, R., Ahmad, S., Ghazali, R., 2001. Properties of Sodium Soap Derived from Palm Based Dihydroxystearic Acid. Journal of Oil Palm Research, Vol 13 (2), pp. 33-38 